\title{
INTEGRATED PATHOGENS AND PESTS MANAGEMENT IN SUSTAINABLE AGRICULTURE
}

\author{
Loredana Suciu ${ }^{1,2}$, Felicia Mureșanu ${ }^{1}$, Laura Şopterean ${ }^{1}$, Ana-Maria Vălean ${ }^{1}$, Felicia Chețan ${ }^{1}$, \\ Camelia Urdă $\breve{l}^{l}$ Alina Șimon ${ }^{l}$, Adina Tărău ${ }^{l, *}$ \\ ${ }^{1}$ Research and Development Station for Agriculture Turda \\ ${ }^{2}$ University of Agricultural Sciences and Veterinary Medicine, Faculty of Agriculture \\ *Corresponding author: \\ Research and Development Station for Agriculture Turda, 27 Agriculturii Street, 401100, Turda, Cluj, Romania \\ Tel:+40264311680(1) \\ Fax: +40264311792 \\ E-mail:tarauadina@yahoo.com
}

http://www.doi.org/10.54574/RJPP.14.02

\begin{abstract}
Attack pathogens and increasing abundance of some insect pests were favored by the climate changes, culture technologies practiced and increasing of cultivated areas with soybeans. The aim of this paper was to evaluate the attack of pathogens in soybean crop and to monitor some pest Lepidoptera species in order to identify technological measures to ensure their control by methods with minimal impact on the environment. The experiment was performed at the Research and Development Station for Agriculture Turda during 2018-2020 period. The best technological option is plowing, balanced fertilization and fungicides application, either alone, or in combination with an insecticide.
\end{abstract}

Keywords: soybean, integrated management, insect pests, diseases

\section{INTRODUCTION}

Soybean, Glycine max L. (Merr.), has a great importance for being versatile in the yield of products for human and animal consumption as well as a high economic value on the intern and international market. Consumption of soybean and its derivatives can be tied to human health, because it contains nutritional characteristics with a high content of protein by adequate nutritional quality, a significant quantity of minerals and fiber, few saturated fats and cholesterol-free (Bischoff et al., 2016). This species is cultivated mainly in the United States, Brazil, and Argentina, India (Table 1). Globally, the area cultivated with soybeans in 2017 was 123.6 million ha (Sobko et al., 2020) and the top three countries together accounted for $80 \%$ of total production that year (Vivek et al., 2020).

Table 1. Soybean cultivated area (2015-2019)

\begin{tabular}{|l|r|r|r|r|r|}
\hline \multirow{2}{*}{ Country } & \multicolumn{5}{c|}{ Cultivated area (ha) } \\
\cline { 2 - 6 } \multicolumn{1}{r|}{ Year } & \multicolumn{1}{|c|}{2015} & \multicolumn{1}{c|}{2016} & \multicolumn{1}{c|}{2017} & \multicolumn{1}{c|}{2018} & \multicolumn{1}{c|}{2019} \\
\hline Argentina & 19.352 .115 & 19.504 .648 & 17.335 .102 & 16.318 .060 & 16.575 .887 \\
\hline Brazil & 32.181 .243 & 33.183 .119 & 33.959 .879 & 34.777 .936 & 35.881 .447 \\
\hline China & 6.507 .748 & 7.094 .841 & 8.247 .992 & 8.415 .791 & 8.426 .405 \\
\hline India & 11.670 .000 & 11.180 .000 & 11.183 .400 & 10.328 .830 & 11.131 .260 \\
\hline USA & 33.123 .470 & 33.470 .290 & 36.236 .750 & 35.448 .420 & 30.352 .150 \\
\hline
\end{tabular}

(FAOSAT 2021, http://www.fao.org/faostat/en/\#data/QC)

Soybean is an important source of food, protein and oil, and therefore numerous researches are needed for increasing its yield under various conditions, including stress. The most important countries in the world with the highest soybean yield are the USA, Brazil, Argentina, China and India (Figure 1) (Pagano \& Miransari, 2016). 


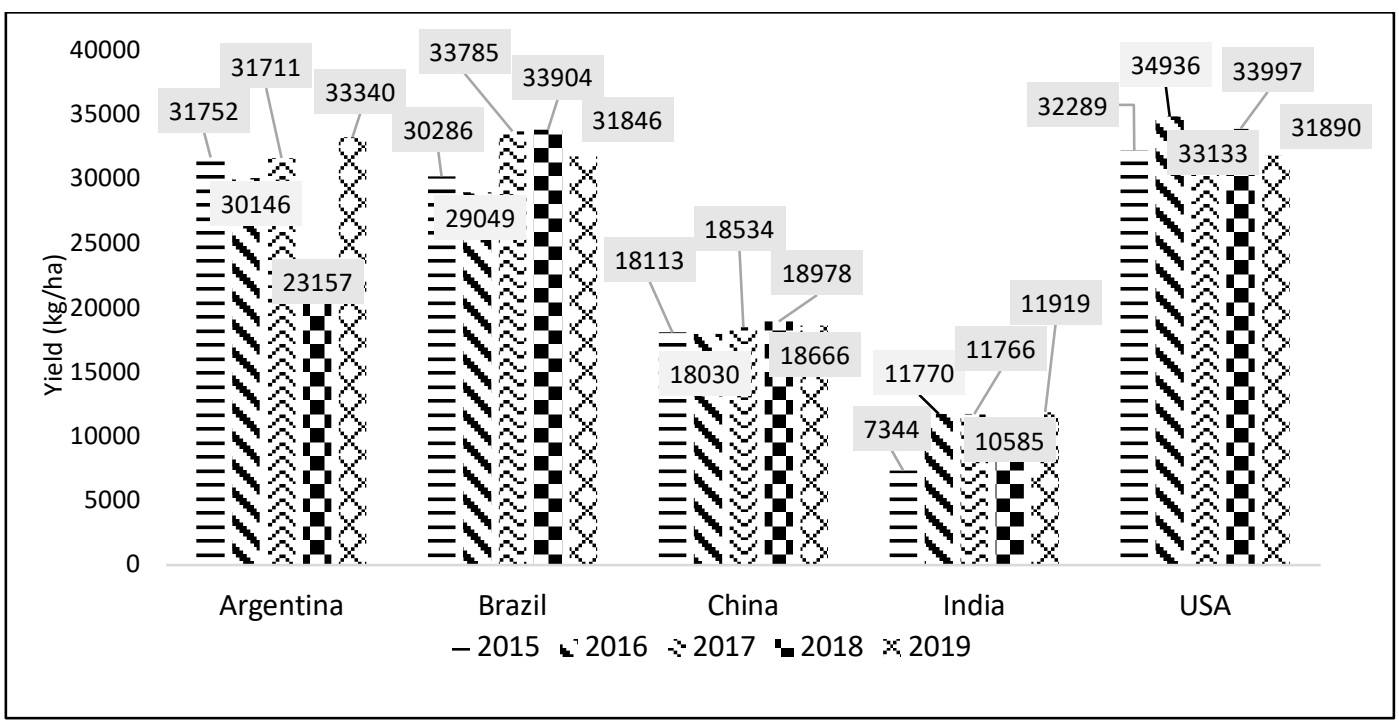

Figure 1. Soybean yields (2015-2019)

(source: FAOSAT 2021, http://www.fao.org/faostat/en/\#data/QC)

Production of this crop can be threatened by a series of biotic (pathogens, pests and weeds) and abiotic (temperature, humidity, excessive fertilization) factors. Diseases and pests showed in recent years that seriously affect soybean crop, especially where proper rotation, proper crop maintenance and phytosanitary treatments are not applied (Hartman et al., 2011).

To find alternatives to intensive agriculture and provide more sustainable options for longterm pests and diseases management, no-till system used to reduce the effects of drought and global warming (Malschi et al., 2018) would be one of the pests and diseases integrated management strategies (Busch et al., 2020). The promotion of predators through the no-tillage system can be diminished if the other pest control measures are not respected (Busch et al., 2020).

One of the integrated pest management approaches is based on large-scale monitoring with pheromone traps to evaluate insect population levels (Furlan \& Kreutzweiser, 2015).

The aim of this paper was to evaluate the attack of pathogens in soybean crop and to monitor some pest Lepidoptera species in order to identify technological measures with minimal impact on the environment. In the integrated management of pests and diseases, observations were made on the impact of technologies (conventional and conservative) on soybean crop.

\section{MATERIALS AND METHODS}

During 2018-2020, at RDSA Turda, effect of technological measures adapted to climate change to limit attack of diseases and pests in soybeans was followed. The biological material was represented by the early soybean variety Teo TD.

Experimental factors: (a) - Tillage system: a 1 - plowing, a $a_{2}-$ minimum tillage - chisel, a3minimum tillage - disk, a - no-tillage; (b) - Fertilization: $\mathrm{b}_{1}-\mathrm{N}_{40} \mathrm{P}_{40} ; \mathrm{b}_{2}-\mathrm{N}_{40} \mathrm{P}_{40}+$ gülle; $\mathrm{b}_{3}-\mathrm{N}_{40} \mathrm{P}_{40}$ + green fertilizer; $\mathrm{b}_{4}-\mathrm{N}_{40} \mathrm{P}_{40} ;+$ gülle + green fertilizer; $(c)$ - Treatment: $\mathrm{c}_{1}-$ untreated, $\mathrm{c}_{2}-$ fungicide, $\mathrm{c}_{3}$ - insecticide, $\mathrm{c}_{4}$ - fungicide + insecticide.

Fertilization: fertilization level: $\mathrm{N}_{40} \mathrm{P}_{40} \mathrm{~kg}$ a.i./ha at the same time as the sowing; organic gülle fertilizer before the sowing $+\mathrm{N}_{40} \mathrm{P}_{40}$ in the same time as the sowing; green fertilizer, precursory to the soybean crop + gülle before sowing $+\mathrm{N}_{40} \mathrm{P}_{40}$ in the same time as sowing.

Weeds, diseases and pests control: pre-emergence herbicide: Sencor 0.35 1/ha + Frontier 1.4 1/ha + 2601 water; post-emergence herbicide: Corum 1.91/ha + 2601 water and Agil 1.0 1/ha; fungicide 
- Copfort (cooper) 3 1/ha; insecticide - Faster (cypermethrin) $100 \mathrm{ml} / \mathrm{ha}$. Pheromone traps were placed at the same time with emergence of soybean crop, pheromone baits were changed monthly and the readings on the sticky plates were made weekly.

During the three experimental years, observations and determinations were made regarding the attack of diseases and the abundance of pest Lepidoptera species. The data from the observations were interpreted using ANOVA and EXCEL.

\section{RESULTS AND DISCUSSIONS}

Continuous increase in average annual and monthly temperatures, the alternation of dry periods with short periods of heavy rainfall confirms that climate change is a certainty (Șimon et al., 2019).

In 2018, a warm year, it can be seen that in April, May and August, the recorded temperatures exceeded the normal by 3 to $5.4^{\circ} \mathrm{C} .2019$ started with low temperatures, below the freezing point, in the first half of January, but which started to grow in the second half of the month (Șimon, 2020). February and March had a warm character and June was characterized as warm with temperatures exceeding the multiannual average by $3.9^{\circ} \mathrm{C}$. In 2020 , the months of the year with the highest temperatures were August and September, with deviations above the 60-year average of $+2.7^{\circ} \mathrm{C}$ and $2.8^{\circ} \mathrm{C}$, respectively (Figure 2).

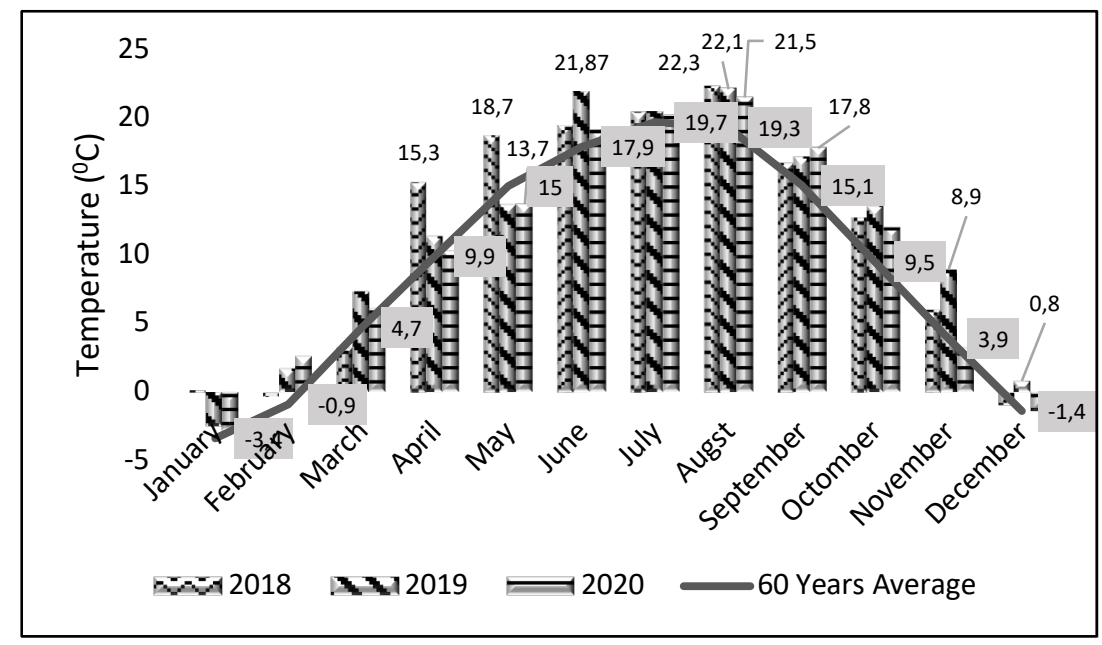

Figure 2. The thermal regime at ARDS Turda (2018-2020)

(source: Turda weather station (longitude: $23^{0} 47$ '; latitude: $46^{0} 35^{\prime}$; altitude: $427 \mathrm{~m}$ ))

Soybean crop suffered the most from the drought during the sowing period, which led to a staggered emergence, effects being visible throughout the vegetation period of 2018 (Şimon et al., 2019). In 2018, rainfall regime was deficient at the beginning of the year, and in February a significant amount of precipitation was registered. The rainfall in June (Figure 3) was welcome for the soybean crop, June being characterized as little rainy. Even if the precipitations were unevenly distributed, 2018 was characterized as a normal year from the pluviometric point of view.

In the year 2019, in January, started with an excess of precipitation, followed by two months with significant decreases in precipitation. April and May makes were characterized as rainy and excessively rainy (Figure 3 ).

The beginning of 2020 was a dry one, registering only $10.4 \mathrm{~mm}, 11.4 \mathrm{~mm}$ less than normal for January. Two rainy months followed, with excessive rainfall in February, and two dry months, with few rainfall (April and May). The rainfall in June exceeded the monthly average by $81.8 \mathrm{~mm}$, characterizing this month excessively rainy (Figure 3 ). 


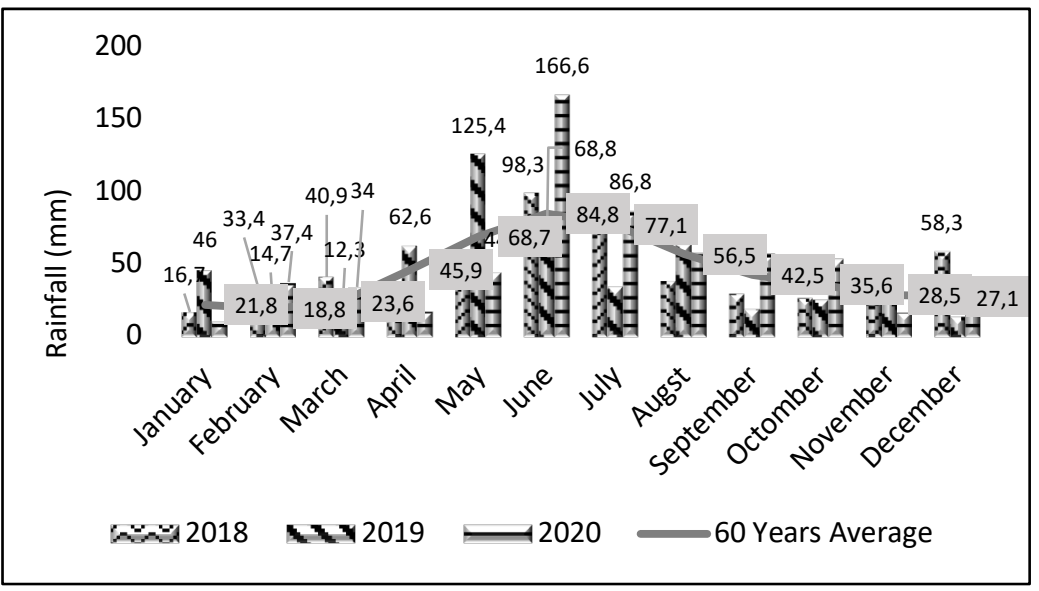

Figure 3. The rainfall regime at ARDS Turda (2018-2020)

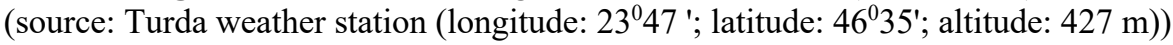

In soybean crop in Transylvanian Plain, the downy mildew (Peronospora manshurica) and bacterial blight attack (Pseudomonas savastanoi pv. glycinea) are most commonly manifested (https://gd.eppo.int). The two diseases can occur simultaneously (with different frequency and intensity) or only one of them, depending on the source of the inoculum and climatic conditions.

The pathogen with the highest frequency in the conditions of the agricultural year 2018 was P. manshurica. From the data presented in Table 2 it shows that the frequency of the attack was between $30 \%$ and $60 \%$ but with an intensity not exceeding $2 \%$ which led to a degree of attack below $2 \%$ in all experimental variants. The highest values were in the minimum tillage system. In the variants where fungicide was applied, the attack was lower.

Table 2. Frequency and intensity of Peronospora manshurica attack (2018)

\begin{tabular}{|c|c|c|c|c|c|c|c|c|c|}
\hline \multirow{3}{*}{$\begin{array}{l}\text { Tillage } \\
\text { system }\end{array}$} & \multirow{3}{*}{ Fertilizer } & \multicolumn{8}{|c|}{ Treatment } \\
\hline & & \multicolumn{2}{|c|}{ Untreated } & \multicolumn{2}{|c|}{ Fungicide } & \multicolumn{2}{|c|}{ Insecticide } & \multicolumn{2}{|c|}{$\begin{array}{c}\text { Fungicide }+ \\
\text { Insecticide }\end{array}$} \\
\hline & & $\mathrm{F} \%$ & $\mathrm{I} \%$ & $\mathrm{~F} \%$ & $\mathrm{I} \%$ & $\mathrm{~F} \%$ & $\mathrm{I} \%$ & $\mathrm{~F} \%$ & $\mathrm{I} \%$ \\
\hline \multirow{4}{*}{ Plowing } & $\mathrm{N}_{40} \mathrm{P}_{40}$ & 50 & 0.74 & 44 & 0.34 & 57 & 0.59 & 48 & 0.44 \\
\hline & $\mathrm{N}_{40} \mathrm{P}_{40}+$ gülle & 58 & 0.94 & 51 & 0.54 & 64 & 0.79 & 55 & 0.64 \\
\hline & $\mathrm{N}_{40} \mathrm{P}_{40}+$ green fertilizer & 55 & 0.69 & 35 & 0.19 & 62 & 0.44 & 47 & 0.29 \\
\hline & $\mathrm{N}_{40} \mathrm{P}_{40}+$ gülle + green fertilizer & 61 & 1.32 & 44 & 0.87 & 64 & 1.12 & 52 & 0.97 \\
\hline \multirow{4}{*}{ Chisel } & $\mathrm{N}_{40} \mathrm{P}_{40}$ & 34 & 1.23 & 41 & 0.68 & 40 & 1.63 & 40 & 0.73 \\
\hline & $\mathrm{N}_{40} \mathrm{P}_{40}+$ gülle & 41 & 1.63 & 48 & 0.88 & 37 & 1.62 & 47 & 0.93 \\
\hline & $\mathrm{N}_{40} \mathrm{P}_{40}+$ green fertilizer & 40 & 1.28 & 29 & 0.53 & 48 & 1.28 & 50 & 0.58 \\
\hline & $\mathrm{N}_{40} \mathrm{P}_{40}+$ gülle + green fertilizer & 41 & 1.96 & 39 & 1.21 & 43 & 1.95 & 49 & 1.26 \\
\hline \multirow{4}{*}{ Disk } & $\mathrm{N}_{40} \mathrm{P}_{40}$ & 40 & 0.97 & 53 & 0.43 & 40 & 1.03 & 42 & 0.43 \\
\hline & $\mathrm{N}_{40} \mathrm{P}_{40}+$ gülle & 47 & 1.17 & 60 & 0.63 & 47 & 1.23 & 49 & 0.63 \\
\hline & $\mathrm{N}_{40} \mathrm{P}_{40}+$ green fertilizer & 43 & 0.82 & 40 & 0.28 & 48 & 0.88 & 45 & 0.28 \\
\hline & $\mathrm{N}_{40} \mathrm{P}_{40}+$ gülle + green fertilizer & 46 & 1.50 & 51 & 0.96 & 48 & 1.56 & 48 & 0.96 \\
\hline \multirow{4}{*}{$\begin{array}{l}\text { No } \\
\text { tillage }\end{array}$} & $\mathrm{N}_{40} \mathrm{P}_{40}$ & 44 & 1.90 & 60 & 0.64 & 46 & 1.37 & 48 & 0.82 \\
\hline & $\mathrm{N}_{40} \mathrm{P}_{40}+$ gülle & 51 & 1.53 & 67 & 0.84 & 53 & 1.37 & 40 & 1.02 \\
\hline & $\mathrm{N}_{40} \mathrm{P}_{40}+$ green fertilizer & 58 & 0.95 & 55 & 0.49 & 55 & 1.02 & 60 & 0.67 \\
\hline & $\mathrm{N}_{40} \mathrm{P}_{40}+$ gülle + green fertilizer & 55 & 1.74 & 62 & 1.17 & 55 & 1.70 & 51 & 1.35 \\
\hline
\end{tabular}

Another common disease in soybean crop is bacterial blight caused by P. savastanoi pv. glycinea, manifested in 2019. This bacterium is transmitted from year to year through infected seeds that do not lose their germination capacity more than $65 \%$. In seeds, the bacterium remains viable for a maximum of 6 months. 
The tillage system influenced the bacterial blight attack. The attack frequency registered the highest values for the variant in which the tillage was not performed (46\% and $49.1 \%)$. Fertilization contributes to the growth and development of plants but also the occurrence and intensity of diseases or pests attack (Table 3). As a conclusion, frequency and intensity of bacterial blight attack were influenced differently, depending on the fertilization variant applied.

Table 3. Frequency and intensity of Pseudomonas savastanoi pv. glycinea attack (2019)

\begin{tabular}{|c|c|c|c|c|c|c|c|c|c|}
\hline \multirow{3}{*}{$\begin{array}{l}\text { Tillage } \\
\text { system }\end{array}$} & \multirow{3}{*}{ Fertilizer } & \multicolumn{8}{|c|}{ Treatment } \\
\hline & & \multicolumn{2}{|c|}{ Untreated } & \multicolumn{2}{|c|}{ Fungicide } & \multicolumn{2}{|c|}{ Insecticide } & \multicolumn{2}{|c|}{$\begin{array}{c}\text { Fungicide }+ \\
\text { Insecticide }\end{array}$} \\
\hline & & $\mathrm{F} \%$ & I\% & $\mathrm{F} \%$ & $\mathrm{I} \%$ & $\mathrm{~F} \%$ & $\mathrm{I} \%$ & $\mathrm{~F} \%$ & $\mathrm{I} \%$ \\
\hline \multirow{4}{*}{ Plowing } & $\mathrm{N}_{40} \mathrm{P}_{40}$ & 27 & 0.27 & 25 & 0.25 & 35 & 0.60 & 21 & 0.21 \\
\hline & $\mathrm{N}_{40} \mathrm{P}_{40}+$ gülle & 22 & 0.22 & 22 & 0.07 & 31 & 0.56 & 30 & 0.47 \\
\hline & $\mathrm{N}_{40} \mathrm{P}_{40}+$ green fertilizer & 29 & 0.68 & 31 & 0.39 & 31.5 & 0.62 & 18.5 & 0.37 \\
\hline & $\mathrm{N}_{40} \mathrm{P}_{40}+$ gülle + green fertilizer & 28 & 0.55 & 19.5 & 0.25 & 17 & 0.26 & 13.5 & 0.14 \\
\hline \multirow{4}{*}{ Chisel } & $\mathrm{N}_{40} \mathrm{P}_{40}$ & 37.5 & 1.12 & 31 & 0.46 & 39.5 & 0.81 & 27.5 & 0.48 \\
\hline & $\mathrm{N}_{40} \mathrm{P}_{40}+$ gülle & 20.5 & 0.26 & 30 & 0.52 & 36.5 & 0.93 & 22.5 & 0.44 \\
\hline & $\mathrm{N}_{40} \mathrm{P}_{40}+$ green fertilizer & 21.5 & 0.44 & 37 & 0.69 & 41 & 0.68 & 35.5 & 0.65 \\
\hline & $\mathrm{N}_{40} \mathrm{P}_{40}+$ gülle + green fertilizer & 43.5 & 0.68 & 43.5 & 1.05 & 42.5 & 0.86 & 31.5 & 0.77 \\
\hline \multirow{4}{*}{ Disk } & $\mathrm{N}_{40} \mathrm{P}_{40}$ & 24 & 0.42 & 22 & 0.36 & 24.5 & 0.80 & 33.5 & 0.89 \\
\hline & $\mathrm{N}_{40} \mathrm{P}_{40}+$ gülle & 33.5 & 0.72 & 28.5 & 0.56 & 32.5 & 1.07 & 29.5 & 0.62 \\
\hline & $\mathrm{N}_{40} \mathrm{P}_{40}+$ green fertilizer & 23 & 0.65 & 35.5 & 0.95 & 21 & 0.38 & 26 & 0.67 \\
\hline & $\mathrm{N}_{40} \mathrm{P}_{40}+$ gülle + green fertilizer & 21.5 & 0.60 & 29 & 0.87 & 46 & 1.03 & 21.5 & 0.52 \\
\hline \multirow{4}{*}{$\begin{array}{l}\text { No } \\
\text { tillage }\end{array}$} & $\mathrm{N}_{40} \mathrm{P}_{40}$ & 33.5 & 0.73 & 40 & 0.69 & 34.5 & 0.46 & 34 & 0.40 \\
\hline & $\mathrm{N}_{40} \mathrm{P}_{40}+$ gülle gulle & 46 & 0.37 & 49.5 & 0.30 & 41 & 0.59 & 40 & 0.49 \\
\hline & $\mathrm{N}_{40} \mathrm{P}_{40}+$ green fertilizer & 32.5 & 0.59 & 45.5 & 0.51 & 43 & 1.00 & 37.5 & 0.41 \\
\hline & $\mathrm{N}_{40} \mathrm{P}_{40}+$ gülle + green fertilizer & 39 & 0.77 & 40 & 0.71 & 40 & 0.37 & 41 & 0.38 \\
\hline
\end{tabular}

Vegetation treatments, especially with fungicides, lead to a decrease in the source of the inoculum and implicitly to a lower degree of attack on these variants. Analyzing the data in table 3 , we can see that the frequency and intensity attack recorded the lowest values for the variety to which fungicide and insecticide were applied. The lowest values of the attack frequency and intensity of $P$. savastanoi pv. glycinea $(13.5 \%$ and $0.14 \%)$ were recorded in the conventional tillage system, in the fertilization variant $\mathrm{N}_{40} \mathrm{P}_{40}+$ gülle + green fertilizer. A low value of the attack intensity was also registered in the variant with fungicide $(0.07 \%)$, in conventional tillage system.

In the climatic conditions of 2019, P. manshurica manifested in the soybean crop. It is known that fertilization, deficient or in excess, is one of the technological links that weaken plants by exposing them to the attack of pathogens. From the data presented in Table 4, we can say that the fertilization variant influenced the attack frequency of this pathogen. At the soil tillage system based on chisel, in the variants where $\mathrm{N}_{40} \mathrm{P}_{40}+$ green fertilizer was applied, the attack frequency was $92.3 \%$, respectively, $91.3 \%$ in the variants where $\mathrm{N}_{40} \mathrm{P}_{40}+$ gülle + green fertilizer was applied, at no-tillage system. These high values of the attack frequency were recorded when no vegetation treatments were applied.

Vegetation treatments are meant to ensure the protection of crops during the vegetation period, by reducing the attack of pathogens and keeping them below the economic threshold of damage. Analyzing the data in Table 4, we can say that fungicide and insecticide treatment negatively influenced the frequency and intensity of downy mildew attack. By applying vegetation treatments, the intensity of the downy mildew attack was reduced, with values between 0.93 and $3 \%$. The highest values of the intensity of the attack $(4.26 \%$ and $5.15 \%)$ were registered for the varieties where no fungicides were applied on the vegetation. 
Table 4. Frequency and intensity of Peronospora manshurica attack (2020)

\begin{tabular}{|c|c|c|c|c|c|c|c|c|c|}
\hline \multirow{3}{*}{$\begin{array}{l}\text { Tillage } \\
\text { system }\end{array}$} & \multirow{3}{*}{ Fertilizer } & \multicolumn{8}{|c|}{ Treatment } \\
\hline & & \multicolumn{2}{|c|}{ Untreated } & \multicolumn{2}{|c|}{ Fungicide } & \multicolumn{2}{|c|}{ Insecticide } & \multicolumn{2}{|c|}{$\begin{array}{l}\text { Fungicide }+ \\
\text { Insecticide }\end{array}$} \\
\hline & & $\mathrm{F} \%$ & $\mathrm{I} \%$ & $\mathrm{~F} \%$ & $\mathrm{I} \%$ & $\mathrm{~F} \%$ & $\mathrm{I} \%$ & $\mathrm{~F} \%$ & $\mathrm{I} \%$ \\
\hline \multirow{4}{*}{ Plowing } & $\mathrm{N}_{40} \mathrm{P}_{40}$ & 44.3 & 1.89 & 61.3 & 0.74 & 39.6 & 1.70 & 67.6 & 0.93 \\
\hline & $\mathrm{N}_{40} \mathrm{P}_{40}+$ gülle & 54.6 & 2.74 & 73.0 & 1.11 & 57.3 & 2.23 & 54.3 & 2.16 \\
\hline & $\mathrm{N}_{40} \mathrm{P}_{40}+$ green fertilizer & 47.6 & 1.96 & 45.3 & 0.99 & 40.3 & 1.32 & 40.0 & 0.98 \\
\hline & $\mathrm{N}_{40} \mathrm{P}_{40}+$ gülle + green fertilizer & 65.0 & 1.75 & 64.6 & 0.90 & 62.3 & 1.64 & 50.3 & 1.35 \\
\hline \multirow{4}{*}{ Chisel } & $\mathrm{N}_{40} \mathrm{P}_{40}$ & 38.3 & 2.02 & 24.6 & 1.46 & 37.3 & 1.35 & 29.0 & 1.22 \\
\hline & $\mathrm{N}_{40} \mathrm{P}_{40}+$ gülle & 42.0 & 2.73 & 41.0 & 1.23 & 58.0 & 1.66 & 52.0 & 0.78 \\
\hline & $\mathrm{N}_{40} \mathrm{P}_{40}+$ green fertilizer & 92.3 & 1.42 & 38.3 & 1.62 & 87.3 & 1.08 & 39.0 & 1.16 \\
\hline & $\mathrm{N}_{40} \mathrm{P}_{40}+$ gülle + green fertilizer & 64.0 & 2.00 & 48.3 & 1.47 & 94.3 & 0.80 & 31.3 & 1.93 \\
\hline \multirow{4}{*}{ Disk } & $\mathrm{N}_{40} \mathrm{P}_{40}$ & 44.3 & 2.63 & 60.6 & 1.11 & 39.6 & 1.49 & 68.3 & 0.98 \\
\hline & $\mathrm{N}_{40} \mathrm{P}_{40}+$ gülle & 55.0 & 1.82 & 72.6 & 0.71 & 57.3 & 1.38 & 53.6 & 1.16 \\
\hline & $\mathrm{N}_{40} \mathrm{P}_{40}+$ green fertilizer & 46.3 & 1.81 & 44.6 & 1.21 & 40.0 & 2.30 & 40.0 & 1.46 \\
\hline & $\mathrm{N}_{40} \mathrm{P}_{40}+$ gülle + green fertilizer & 64.6 & 1.18 & 64.6 & 1.70 & 62.0 & 0.99 & 47.6 & 1.46 \\
\hline \multirow{4}{*}{$\begin{array}{l}\text { No } \\
\text { tillage }\end{array}$} & $\mathrm{N}_{40} \mathrm{P}_{40}$ & 59.0 & 2.49 & 33.6 & 1.73 & 20.3 & 3.10 & 42.3 & 1.33 \\
\hline & $\mathrm{N}_{40} \mathrm{P}_{40}+$ gülle & 53.0 & 4.26 & 67.0 & 1.31 & 36.3 & 5.15 & 47.0 & 3.00 \\
\hline & $\mathrm{N}_{40} \mathrm{P}_{40}+$ green fertilizer & 35.0 & 3.00 & 30.0 & 2.59 & 43.3 & 3.11 & 47.6 & 0.90 \\
\hline & $\mathrm{N}_{40} \mathrm{P}_{40}+$ gülle + green fertilizer & 91.3 & 3.00 & 89.0 & 1.22 & 78.0 & 3.00 & 45.0 & 2.73 \\
\hline
\end{tabular}

In our experience, in addition to the tillage system, fertilization and treatments, we resorted to limiting the attack of Lepidoptera by using pheromone traps. In this regard, we tried to quantify insect species, which have a high frequency of catching in sex pheromone traps (biotechnical method). The main areas of pheromone use are detection, population monitoring and mating. These approaches of pheromones are based on their role as mediators of insect reproduction (Islam, 2012). Tewari et al., (2014) state that uses of pheromones in the context of integrated pest management would be population monitoring and suppression. Interruption of mating, attraction and mass capture of pests are some of the most common direct control tactics, which depend on the use of pheromones (Ivaş \& Mureşanu, 2011). Thus, it is possible to identify areas where populations are high enough to lead to reduced production (Furlan \& Kreutzweiser, 2015).

The pests reported were pest lepidopteran species: Agrotis segetum (turnip moth), Autographa gamma (silver Y) and Mamestra oleracea (bright-line brown-eye). Thus, taking into account the period June-September, in which the species were monitored, catch values were lower in 2019 compared to the other two years (2018 and 2020), in all soil tillage systems, probably due, large amounts of precipitation from this year. The abundance of $A$. segetum species reaches higher thresholds than the other two monitored pests, in all years and all tillage systems (Figure 4).

Conservative tillage systems play a positive role in the formation and development of insect populations (Pearsons \& Tooker, 2017; Stinner \& House, 1990; Busch et al., 2020; Rowen et al., 2020), so that, in the no-tillage system there is a higher number of adults caught than in other systems (Figure 4). Therefore, we suggest that in the case of reduced minimum work, more attention be paid to insect monitoring and phytosanitary treatments, when the economic damage threshold is exceeded. 


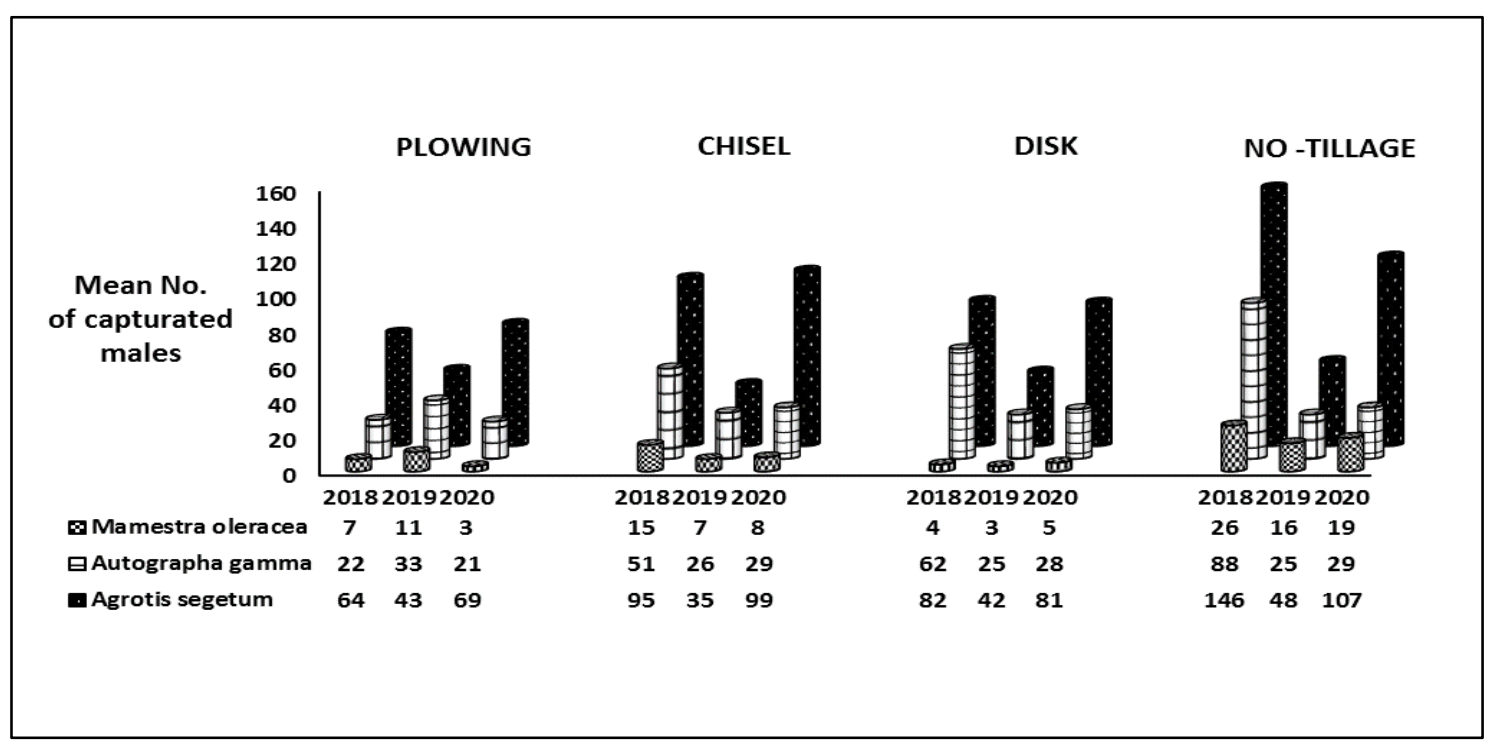

Figure 4. Abundance (number) of pest Lepidoptera species in four tillage systems (ARDS Turda, 2018-2020)

\section{CONCLUSIONS}

The spectrum of diseases in a crop may change from year to year, depending on climatic conditions, the source of the inoculum, the cultivated genotype or the technology applied. Disease control involves choosing a technology adapted to any situation present in an agricultural year, in a certain crop, but which to be part of a sustainable agriculture. From this study we can conclude that to reduce the attack of soybean pathogens Peronospora manshurica and Pseudomonas savastanoi pv. glycinea, the best technological variant is plowing, a balanced fertilization and application of fungicides, alone or in combination with an insecticide.

The strong effect of the soil works system on the abundance of Lepidoptera Agrotis segetum, Autographa gamma and Mamestra oleracea was noticed. The strongest effect in increasing their abundance is the no-tillage system, especially for the populations of $A$. segetum, the most abundant and dangerous.

Pest populations may be limited below PED or, even, controlled by this non-polluting method (synthetic sex pheromone traps), which obligatory should be introduced into the sustainable technologies with low environmental impact.

\section{ACKNOWLEDGEMENTS}

This work was supported by a grant of the Romanian Ministery of Research and Innovation, CCCDI-UEFISCDI, project number PN-III-P1-1.2-PCCDI2017-0301, contract no. 28PCCDI.

\section{REFERENCES}

BISCHOFF, T.Z., COELHO, S.R.M., SCHOENINGER, V., CASSOL, F.D.R., DO PRADO, N.V., CHRIST, D. (2016). Technological quality of soybean oil obtained from stored grain under controlled environmental conditions. Engenharia Agrícola, 36, 1145-1156.

BUSCH, A.K., DOUGLAS, M.R., MALCOLM, G.M., KARSTEN, H.D., AND TOOKER, J.F. (2020). A high-diversity/IPM cropping syst 'em fosters beneficial arthropod populations, limits invertebrate pests, and produces competitive maize yields. Agriculture, Ecosystems and Environment, 292, 106812. 
FURLAN, L., KREUTZWEISER, D. (2015). Alternatives to neonicotinoid insecticides for pest control: Case studies in agriculture and forestry. Environment Science Pollution Research, 22, 135-147.

HARTMAN, G.L., WEST, E.D., HERMAN, T.K. (2011). Crops that feed the world 2. Soybean-worldwide production, use, and constraints caused by pathogens and pests. Food Security, 3, 5-17.

ISLAM, M.A. (2012). Pheromone use for insect control: present status and prospect in Bangladesh. International Journal of Agricultural Research, Innovation and Technology, 2, 1, 47-55.

IVAŞ, A., MUREŞANU, F. (2011). The abundance and dynamics of Lepidoptera pests from maize, soybean, sugar beet crops, in conditions of Agricultural Research and Development Station Turda. Buletinul Universităţii de Ştiinţe Agricole şi Medicină Veterinară Cluj-Napoca, Ed. AcademicPres, 68, 1, 438-444.

MALSCHI, D., TĂRĂU, A.D., VĂLEAN, A.M., ŞOPTEREAN, L., SUCIU, A.L., DĂRAB, I.D., CHEŢAN, C., TRITEAN, N. (2018). Wheat pest dynamics, forecasting and current importance of the attack, to develop integrated control system in the center of Transylvania (ARDS Turda, 2006-2016). Romanian Agricultural Research, 35, 203-2020.

PAGANO M.C., MIRANSARI M. (2016). The importance of soybean production worldwide. Abiotic and Biotic Stress in Soybean Production, 1, 1-26.

PEARSONS, K.A., TOOKER, J. F. (2017). In-field habitat management to optimize pest control of novel soil communities in agroecosystems. Insects, 8, 82. Doi:10.3390/insects8030082

ROWEN, E.K., REGAN, K.H., BARBERCHECK, M.E., TOOKER, J.F. (2020). Is tillage beneficial or detrimental for insect and slug management? A meta-analysis. Agriculture, Ecosystems and Environment, 294, 105-113.

SOBKO, O., ZIKELI, S., CLAUPEIN, W., GRUBER, S. (2020). Seed yield, seed protein, oil content, and agronomic characteristics of soybean (Glycine max L. Merrill) depending on different seeding systems and cultivars in Germany. Agronomy, 10, 1-12. Doi:10.3390/agronomy10071020

STINNER, B.R., HOUSE, G.J. (1990). Arthropods and other invertebrates in conservation-tillage agriculture. Annual Review of Entomology, 35, 299-318.

ȘIMON, A., CHEȚAN, F., OLTEAN, V. (2019). Caracterizarea climatică a anului 2018 și influența acestuia asupra producției la principalele culturi agricole. Agricultuta Transilvană, 30, 11-17.

ȘIMON, A. (2020). Caracterizarea climatică a anului 2019, în zona Turda. Agricultura Transilvană, 32, 913.

TEWARI S., LESKEY, T. C., NIELSEN, A. L., PIÑERO, J.C., RODRIGUEZ-SAONA, C.R. (2014). Use of pheromones in insect pest management, with special attention to weevil pheromones. Integrated Pest Management - Current concepts and ecological perspective, 9, 141-168.

VIVEK, V., LARREA, C., BERMUDEZ, S. (2020). Global market report: Soybeans. International Institute for Sustainable Development. Available from: https://www.iisd.org/system/files/2020-10/ssiglobal-market-report-soybean.pdf

WRIGHT, D. L., FERRELL, J. A., SMALL, I. (2002). Soybean Production in Florida. Institute of Food and Agricultural Sciences, University of Florida, Extension, SS-AGR-182, 50. Available from: http://edis.ifas.ufl.edu.

***http://www.fao.org/faostat/en/\#data/QC

$* * *$ https://gd.eppo.int/ 